\title{
APPLICATION OF LIQUID DESICCANT DEHUMIDIFICATION TO AMINE-BASED CARBON CAPTURE SYSTEMS
}

\author{
Christopher L. Martin, Bruce C. Folkedahl, David J. Dunham, and John P. Kay \\ Energy \& Environmental Research Center \\ University of North Dakota \\ 15 North 23rd Street, Stop 9018 \\ Grand Forks, ND USA 58202-9018 \\ E-mail: cmartin@undeerc.org, bfolkedahl@undeerc.org, ddunham@undeerc.org, and \\ jkay@undeerc.org \\ Corresponding Author: Christopher L. Martin \\ Telephone: (701) 777-5083 \\ Fax: (701) 777-5181 \\ E-mail: cmartin@undeerc.org
}




\title{
APPLICATION OF LIQUID DESICCANT DEHUMIDIFICATION TO AMINE-BASED CARBON CAPTURE SYSTEMS
}

\author{
Christopher L. Martin, Bruce C. Folkedahl, David J. Dunham, and John P. Kay \\ Energy \& Environmental Research Center \\ University of North Dakota \\ 15 North 23rd Street, Stop 9018 \\ Grand Forks, ND 58202-9018
}

\begin{abstract}
Liquid desiccant-based dehumidification with water recovery is an effective and robust method to remove excess moisture from process gas streams and recover relatively high quality product water. A study was undertaken to determine if desiccant-based technology could be applied to the benefit of an amine-based $\mathrm{CO}_{2}$ capture system since the addition of $\mathrm{CO}_{2}$ capture to a coal-fired power plant can significantly increase the plant's consumptive water use. Test data with a pilot flue gas moisture recovery system are presented to illustrate the characteristics of the process, including the water recovery potential, product water quality, and thermal energy consumption. The process is then evaluated theoretically under conditions typical of a monoethanolamine-based $\mathrm{CO}_{2}$ capture process. The analysis indicates that there is less opportunity for moisture recovery compared to a plant without $\mathrm{CO}_{2}$ capture because of the cooler processing temperatures associated with $\mathrm{CO}_{2}$ absorption and stripping. However, a desiccantbased dehumidification system might be useful as a heat-driven moisture management tool since desiccant-based moisture removal is more effective than dew point cooling for a given heat rejection temperature. Dehumidifying the $\mathrm{CO}_{2}$ product stream prior to compression might offer incremental power consumption savings compared to other options of moisture vapor management.
\end{abstract}

Keywords: water recovery, liquid desiccant dehumidification, amine $\mathrm{CO}_{2}$ absorption

\section{INTRODUCTION}

Water consumption is a key concern for all utility-scale power production. Access to sufficient water for cooling can delay permitting, introduce added costs, and even lead to the cancellation of projects. Unfortunately, it seems clear that the water intensity of power production will only increase with the addition of a carbon dioxide recovery (CDR) system. According to baseline studies presented by the U.S. Department of Energy (DOE) National Energy Technology Laboratory (NETL) (2009), pulverized coal plants could experience the most dramatic increase in water consumption, as shown in the trends of Figure 1. Much of the additional water consumption goes to serve the added cooling load introduced by the aminebased CDR system, as shown in the breakdown of Table 1 (U.S. Department of Energy National Energy Technology Laboratory, 2009). Dry cooling options using air as the heat rejection 


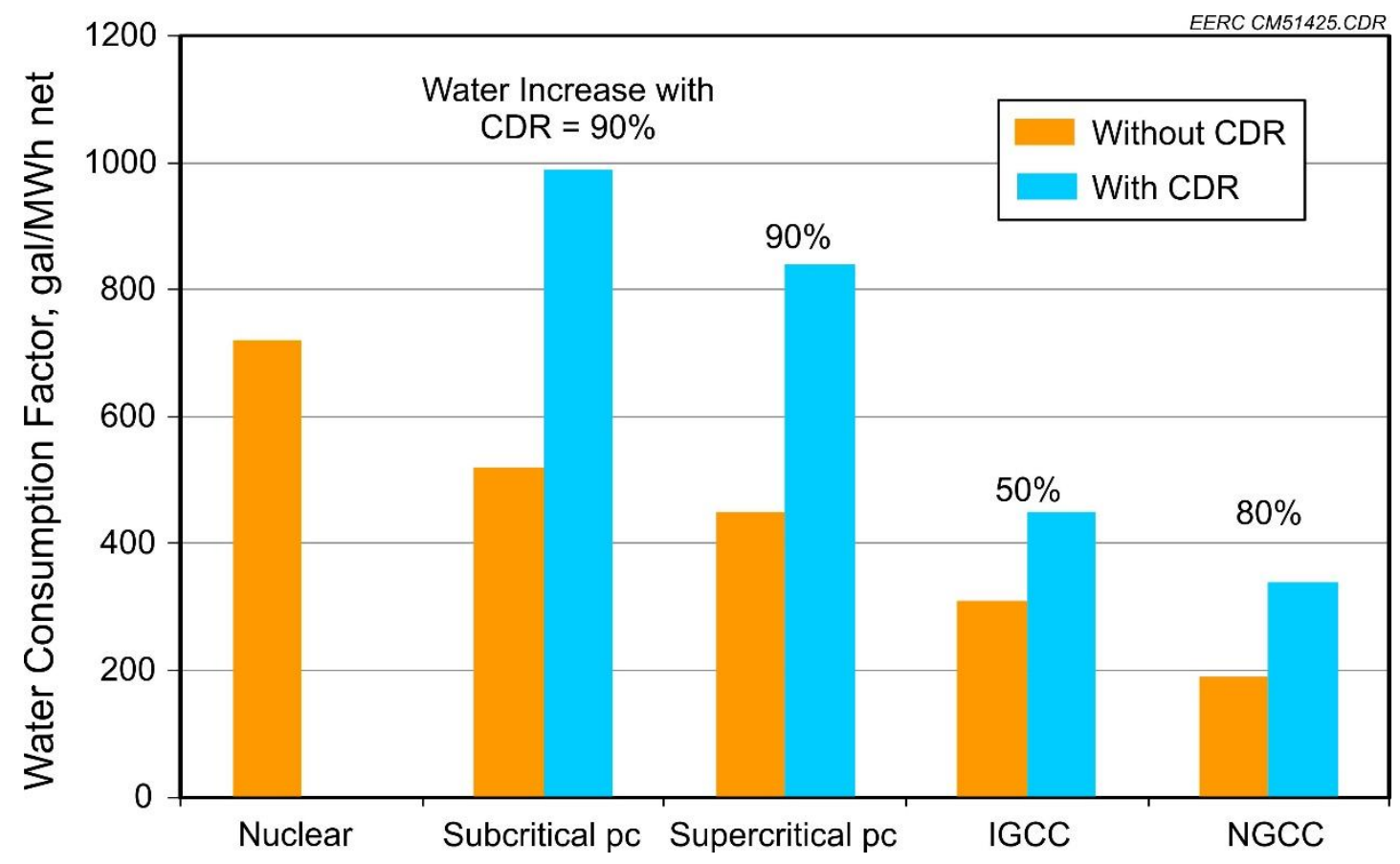

Figure 1. Estimated changes in water intensity by adding monoethanolamine (MEA)-based $\mathrm{CO}_{2}$ capture to various power production cycles (U.S. Department of Energy National Energy Technology Laboratory, 2009) (pc is pulverized coal; IGCC is integrated gasification combined cycle; NGCC is natural gas combined cycle).

Table 1. Breakdown of Major Water Uses for a Supercritical pc Plant (U.S. Department of Energy National Energy Technology Laboratory, 2009)

\begin{tabular}{lcc}
\hline & Without $\mathbf{C O}_{2}$ Capture & With MEA-Based CO $\mathbf{C}_{2}$ Capture \\
\hline Cooling Tower Makeup & $88.7 \%$ & $91.5 \%$ \\
FGD $^{1}$ Makeup & $10.0 \%$ & $7.5 \%$ \\
Boiler Feed Makeup & $1.3 \%$ & $1.0 \%$ \\
\hline
\end{tabular}

${ }^{1}$ Flue gas desulfurization.

medium are available, and studies subsequent to the NETL baseline cases evaluated the impact of using dry cooling for at least the power cycle's steam condensation load (Zhai et al., 2011). That study showed that switching to an air-cooled condenser lessened the water consumption for a CDR-equipped pulverized coal plant to roughly match that of a non-CDR plant with wet cooling. However, both of these studies assumed a $\mathrm{CO}_{2}$ capture rate of $90 \%$. Recently, the issue of increased water consumption with CDR was reevaluated with respect to (at the time) proposed U.S. Environmental Protection Agency emission performance standards for new coal-fired electric generation units (Talati et al., 2014). For a regulatory limit of $1100 \mathrm{lb} \mathrm{CO} / \mathrm{MWh}$ gross (500 kg CO $2 / \mathrm{MWh}$ gross), the authors concluded that water consumption would increase by about $31 \%$ from the addition of CDR. 
The moisture content of flue gas is a potential source of makeup water for power plant operations. While the quantity of recoverable flue gas moisture is far too small to offset cooling tower losses, it can be sufficient to approach the makeup needs for secondary plant processes such as FGD or boiler feedwater. With respect to operation of an amine-based CDR system, situations have been identified where the $\mathrm{CO}_{2}$ absorption and stripping process can operate on a water-neutral basis by cooling the flue gas below its dew point and retaining water in the process (Hetland, 2013). Of course the source of cooling matters since, if evaporative wet cooling is used, water loss is simply transferred to the cooling tower. In the case of using cold seawater, dew point cooling could save the trouble of sourcing freshwater makeup (Kvamsdal et al., 2010), but most other locations would need to consider air cooling which is more limiting. Of the coalfired, amine-based CDR, examples evaluated by Hetland (2013), only the high moisture lignite case appears to result in a water-neutral temperature that could feasibly be met by dry cooling.

\section{LIQUID DESICCANT DEHUMIDIFICATION WITH MOISTURE RECOVERY}

Liquid desiccant dehumidification is a proven and robust method to remove excess moisture from process gas streams. These systems employ a hygroscopic medium that can absorb moisture at vapor pressures below the saturation pressure of pure water. Therefore, they have an expanded range of water-harvesting conditions relative to dew point condensation, albeit at the expense of increased thermal energy needed for regeneration.

The Energy \& Environmental Research Center (EERC) has investigated the use of liquid desiccant-based systems for a number of power production applications, including flue gas moisture recovery (Folkedahl et al., 2006), pollutant scrubbing (Martin and Zhuang, 2014), and power plant cooling (Martin and Pavlish, 2013). Liquid desiccant dryers are commonly specified for amine-based CDR to remove moisture from the intercooler stages of the $\mathrm{CO}_{2}$ compression train. However, these systems are designed to dry the $\mathrm{CO}_{2}$ to achieve dew point specifications for pipeline transport and they frequently employ triethylene glycol (TEG) as the liquid desiccant instead of a $\mathrm{CaCl}_{2}$-based solution that is preferred for many of the previously mentioned applications. Compared to $\mathrm{CaCl}_{2}$, TEG has a more limited moisture exchange capacity, which makes it less desirable for bulk moisture recovery, but it is a superior drying agent for removing trace quantities of moisture vapor. For instance, liquid TEG can absorb moisture to achieve a $-40^{\circ} \mathrm{C}$ pipeline dew point specification, a moisture level that would completely dry out a liquid $\mathrm{CaCl}_{2}$ solution, leaving only a solid hydrate crystal.

Liquid desiccant moisture recovery is similar to conventional gas-drying systems except that desiccant regeneration takes place in a sealed flash evaporator so that product water can be recovered by condensing the vapor in a condenser. A simplified schematic of the process is shown in Figure 2. According to the figure, a concentrated liquid desiccant solution is used to absorb moisture directly from the process gas in a counterflow absorber; the exiting working fluid that is diluted with absorbed moisture, or weak solution, is then heated and pumped to an evaporator where the moisture flashes from solution and is condensed to generate liquid water product. The concentrated desiccant, or strong solution, exiting the evaporator is then cooled and is ready to complete the cycle by absorbing additional moisture vapor in the absorber. 


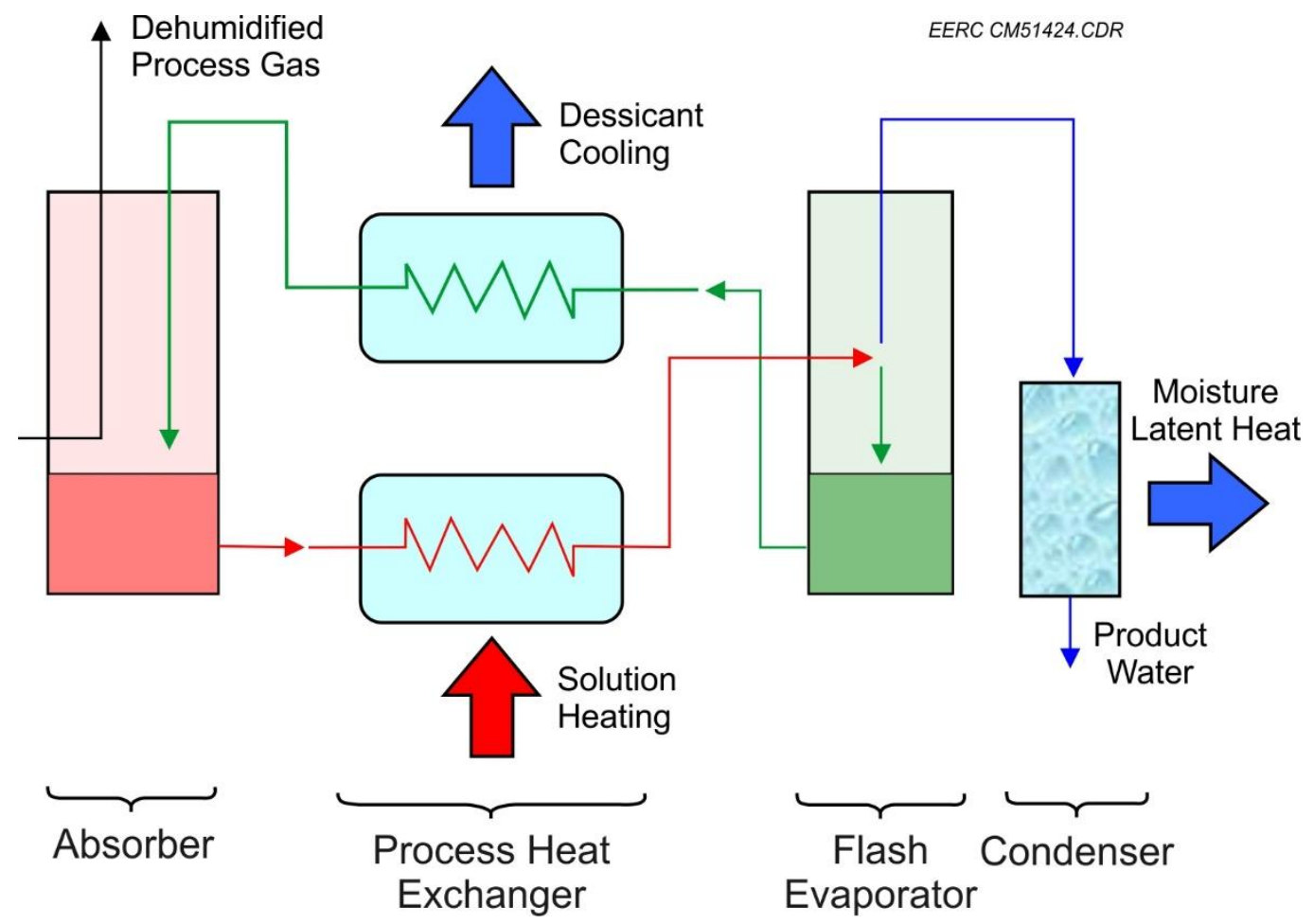

Figure 2. Diagram of a liquid desiccant dehumidification system (LDDS) with product water recovery.

The liquid desiccant process is primarily heat-driven and is not unlike the fundamental process of amine-based absorption and stripping for $\mathrm{CO}_{2}$ capture. As such, liquid desiccant moisture removal has the potential to remove moisture from a process stream using significantly less mechanical power compared to other options like dew point cooling or compression with condensate separation.

\section{PILOT TEST EXPERIENCE}

A liquid desiccant flue gas moisture recovery system was fabricated and tested in conjunction with one of the EERC's pilot-scale combustion test facilities. The moisture recovery system was fitted to the exhaust stream of a pulverized coal-fired system known as the combustion test furnace (CTF). The EERC's CTF is a $550,000-\mathrm{Btu} / \mathrm{hr}(160 \mathrm{~kW}$ th) pulverized coal pilot plant test furnace and was originally constructed in 1967 to evaluate the influence of variables such as ash composition, excess air, gas temperature, and tube wall temperatures on ash fouling. In addition to these original uses, it has also been modified to also allow evaluation of a number of back-end pollution control technologies including postcombustion amine-based $\mathrm{CO}_{2}$ capture and precombustion $\mathrm{CO}_{2}$ separation with oxygen-firing.

For these tests, the liquid desiccant system was designed to treat the flue gas exhaust from the $\mathrm{CO}_{2}$ absorber of a MEA-based CDR system. A solution of $\mathrm{CaCl}_{2}$ and water was used as the dehumidification agent. $\mathrm{CaCl}_{2}$ was chosen based on an evaluation completed during the initial 
evaluation of this concept (Folkedahl et al., 2006) where it ranked high in key criteria such as low cost, moderate corrosivity, and relatively benign environmental impacts in case of accidental release. Thermophysical properties of $\mathrm{CaCl}_{2}$ desiccant mixtures, including vapor pressure, saturation concentration, specific heat, etc., were calculated using property correlations available in the literature (Conde, 2004).

Figure 3 shows the as-tested connection schematic for the liquid desiccant system. This schematic is fundamentally identical to the concept presented in Figure 2, but it includes transducer locations and ancillary equipment such as pumps, storage tanks, valves, etc. The flash evaporator operated at subatmospheric pressure to improve the efficiency of moisture recovery, and this pressure differential was maintained by isolating the evaporator and condenser between two liquid-filled barometric legs, one for the strong desiccant and one for the product water. Noncondensable gases that accumulated in the condenser were evacuated using a liquid ring vacuum pump. The absorption column was fabricated from 12-inch $(30.5$-cm)-diameter, Schedule 10, 316 stainless steel pipe, and it was filled with 3-inch $(7.62-\mathrm{cm})$ plastic gas/liquid

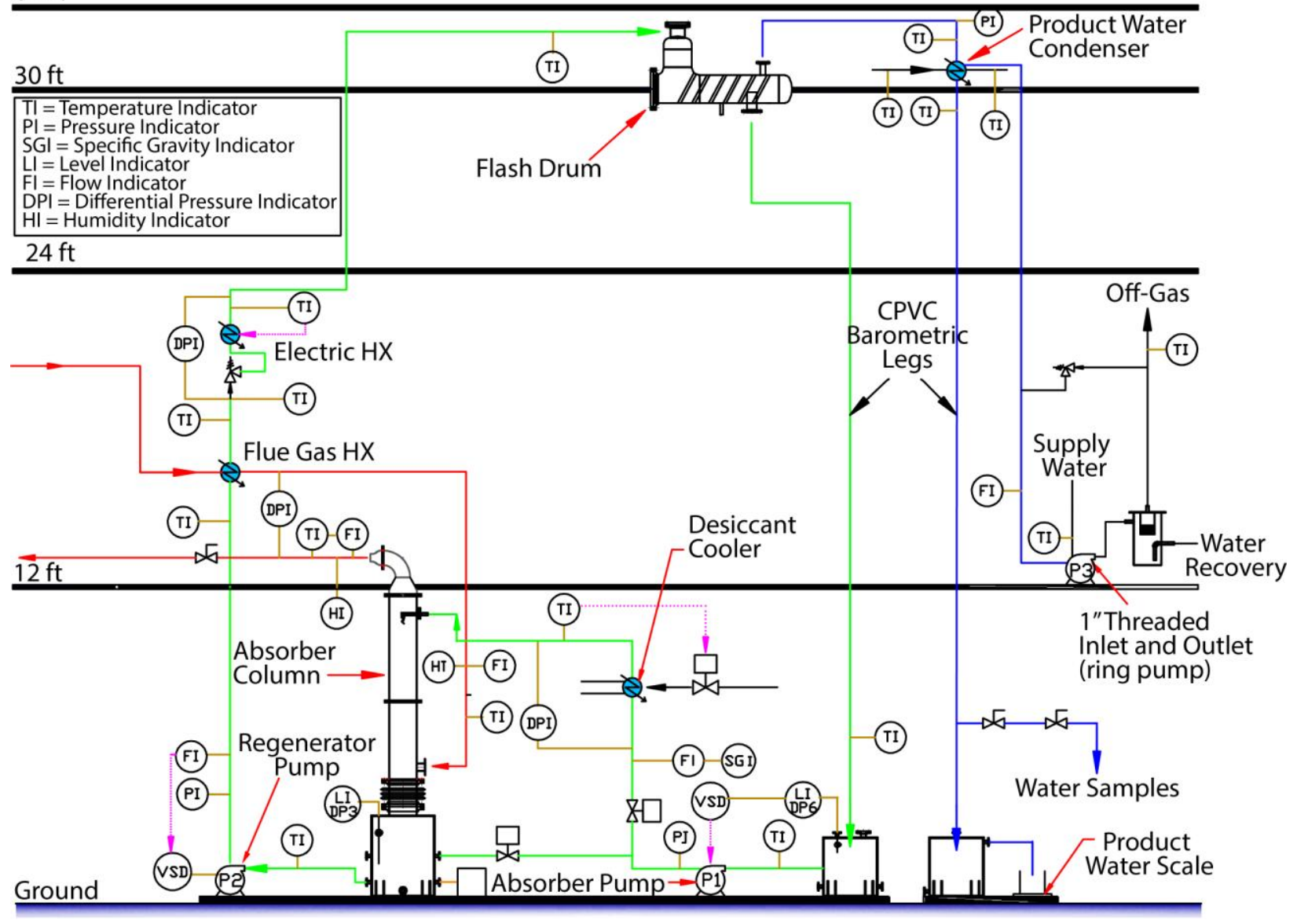

Figure 3. Connection diagram for the pilot liquid desiccant moisture recovery system. 
distribution saddles to a depth of approximately $6 \mathrm{ft}(1.83 \mathrm{~m})$ to increase contact area between the flue gas and the desiccant. Strong desiccant was pumped into the top of the absorber column and onto plastic gas/liquid distribution saddles through a single 1-inch $(2.54-\mathrm{cm})$ pipe. A Teflon screen mist eliminator was installed at the top of the column to prevent the loss of entrained liquid droplets.

Figure 4 shows a three-dimensional drawing of the system's installed layout. Further details of the pilot system are provided elsewhere (Folkedahl et al., 2010).

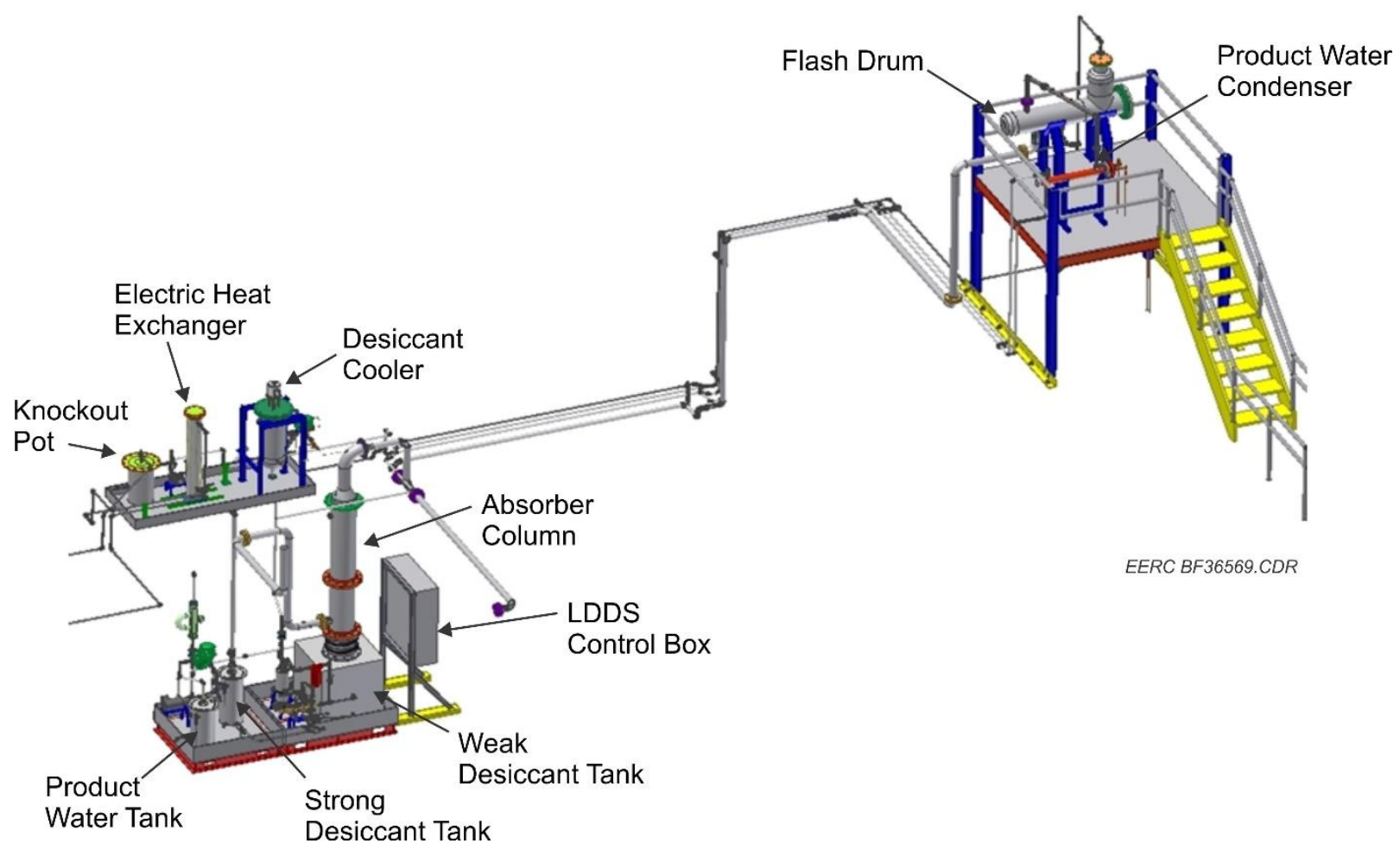

Figure 4. Three-dimensional drawing of the LDDS pilot system.

Four days of extended-duration tests ranging from 4 to 10 hours each were conducted to shake down operation of the system. The process gas stream for these tests was a coal-derived flue gas that had undergone conventional pollutant control (particulates, $\mathrm{SO}_{2}$ ) and $\mathrm{CO}_{2}$ capture upstream of the desiccant absorber. Particulates were removed in an ESP, $\mathrm{SO}_{2}$ was removed using a wet FGD system and a polishing scrubber, and $\mathrm{CO}_{2}$ was removed in a MEA-based scrubber. A summary of the gas composition entering the desiccant absorber for each test day is provided in Table 2. As the data indicate, by the time the flue gas reached the moisture recovery system, it was basically saturated $\mathrm{N}_{2}$ with small fractions of $\mathrm{O}_{2}$ and $\mathrm{CO}_{2}$. 
Table 2. Summary of Gas Composition* Entering the Desiccant Absorber on a Dry Basis

\begin{tabular}{lccccc}
\hline & $\mathbf{O}_{\mathbf{2}}, \boldsymbol{\%}$ & $\mathbf{C O}_{\mathbf{2}}, \boldsymbol{\%}$ & $\mathbf{C O}, \mathbf{p p m v}$ & $\mathbf{S O}_{2}, \mathbf{p p m v}$ & $\mathbf{N O}_{\mathbf{x}}, \mathbf{p p m v}$ \\
\hline Day 1 & 5.28 & 1.54 & 2.65 & $<1$ & 137.03 \\
Day 2 & 5.39 & 1.93 & 3.21 & $<1$ & 158.85 \\
Day 3 & 5.44 & 1.25 & 2.29 & 1.68 & 2.50 \\
Day 4 & 5.42 & 1.27 & 2.01 & $<1$ & 7.29 \\
\hline
\end{tabular}

* Balance assumed to be $\mathrm{N}_{2}$.

\subsection{Water Recovery}

A summary of the averaged steady-state test results and operating conditions for the liquid desiccant moisture recovery system is provided in Table 3 for each test day. Controlled test parameters included the heating temperature set point of the weak desiccant and the cooling temperature set point for the strong desiccant since these defined the heat source and heat

Table 3. Summary of LDDS Operating Conditions

\begin{tabular}{|c|c|c|c|c|}
\hline Test Day & Day 1 & Day 2 & Day 3 & Day 4 \\
\hline \multicolumn{5}{|l|}{ System Flow Rates } \\
\hline LDDS Inlet Gas Flow, $\mathrm{m}^{3} / \mathrm{hr}\left(20^{\circ} \mathrm{C}, 1 \mathrm{~atm}\right)$ & 114 & 113 & 111 & 104 \\
\hline Nominal Strong Desiccant Circulation Rate, $\mathrm{kg} / \mathrm{hr}$ & 910 & 919 & 949 & 955 \\
\hline Absorber Desiccant Liquid-to-Gas Ratio, kg/kg & 6.61 & 6.73 & 7.10 & 7.64 \\
\hline \multicolumn{5}{|l|}{ Water Harvesting } \\
\hline Moisture Content of Inlet Gas Flow, $\mathrm{kg} / \mathrm{hr}$ & 7.2 & 7.1 & 7.0 & 6.4 \\
\hline Moisture Content After LDDS, kg/hr & 2.6 & 2.5 & 2.3 & 2.3 \\
\hline Absorbed Moisture by LDDS, kg/hr & 4.6 & 4.5 & 4.7 & 4.1 \\
\hline Moisture Capture by LDDS, \% & 64 & 64 & 67 & 64 \\
\hline \multicolumn{5}{|l|}{ Desiccant Concentration } \\
\hline $\begin{array}{l}\text { Test Period Beginning Strong Solution Concentration, } \\
\text { mass fraction } \mathrm{CaCl}_{2}\end{array}$ & 0.458 & 0.491 & 0.506 & 0.518 \\
\hline $\begin{array}{l}\text { Test Period Ending Strong Solution Concentration, mass } \\
\text { fraction } \mathrm{CaCl}_{2}\end{array}$ & 0.475 & 0.523 & 0.510 & 0.523 \\
\hline Average Water Loss from Desiccant, $\mathrm{kg} / \mathrm{hr}$ & 1.7 & 2.8 & 0.5 & 1.3 \\
\hline \multicolumn{5}{|l|}{ System Temperatures } \\
\hline Absorber Inlet Gas Temp., ${ }^{\circ} \mathrm{C}$ & 42.6 & 42.5 & 42.6 & 42.1 \\
\hline Absorber Outlet Gas Temp., ${ }^{\circ} \mathrm{C}$ & 51.0 & 52.8 & 51.6 & 53.5 \\
\hline Evaporator Outlet Strong Solution Temp., ${ }^{\circ} \mathrm{C}$ & 67.0 & 67.3 & 68.9 & 70.0 \\
\hline Absorber Inlet Strong Solution Temp., ${ }^{\circ} \mathrm{C}$ & 52.2 & 54.0 & 52.1 & 54.7 \\
\hline Absorber Outlet Weak Solution Temp., ${ }^{\circ} \mathrm{C}$ & 54.0 & 55.9 & 54.4 & 56.4 \\
\hline Evaporator Inlet Weak Solution Temp., ${ }^{\circ} \mathrm{C}$ & 76.9 & 79.8 & 78.5 & 80.2 \\
\hline
\end{tabular}


rejection interface temperatures. The heating temperature of the weak solution was $80^{\circ} \mathrm{C}$, which was considered low enough to be supplied by low-pressure steam or, possibly, another waste heat resource at the plant. The targeted absorber inlet strong solution temperature was $52^{\circ} \mathrm{C}$ and was based on an estimate for the achievable cooling temperatures using an air-cooled heat exchanger. The exhaust gas stream from the CTF's $\mathrm{CO}_{2}$ absorber was actually cooler than the strong solution entering the desiccant absorber during these tests, so the gas stream was heated by the desiccant as it passed through the absorber.

The desiccant concentration data of Table 3 suggest that true steady-state conditions were not reached since the desiccant concentration increased during the course of each run, meaning that the desiccant solution experienced a net loss of moisture beyond the amount absorbed from the flue gas. This water loss is put into context in Figure 5, which shows that the total product water harvested (out values) consisted of contributions from moisture absorbed from the flue gas, but also from a smaller quantity of water given up by the desiccant because of overheating the weak solution before flashing (in values). With process feedback, the heating temperature of the weak solution could have been reduced so that the amount of flashing was reduced to keep the desiccant concentration virtually constant.

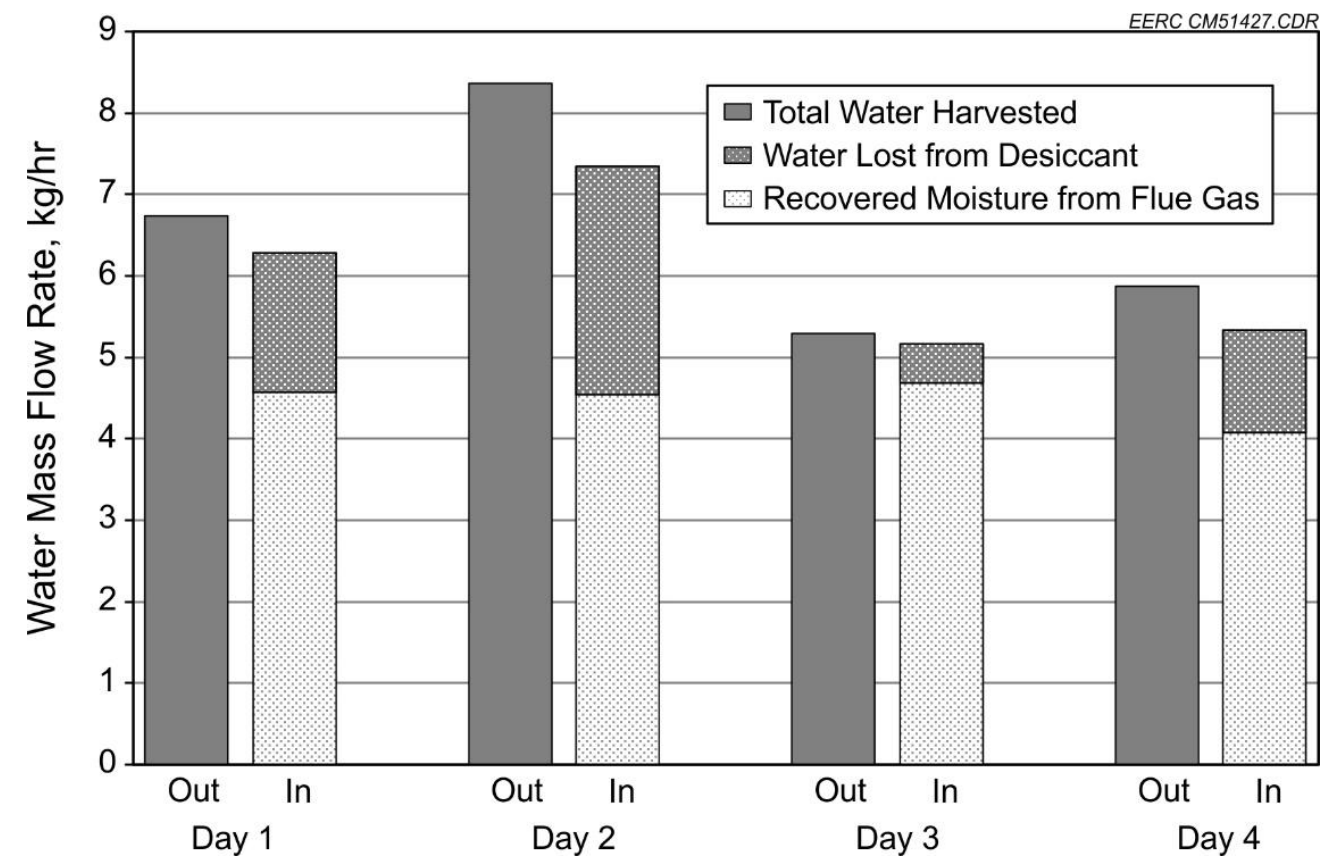

Figure 5. LDDS water mass balance summary.

The water-harvesting results in Table 3 show that the LDDS was able to remove $64 \%-67 \%$ of the moisture vapor entering the desiccant absorber. When compared to the estimated vapor pressure of the incoming strong desiccant solution, this level of capture suggests a nearequilibrium removal of moisture vapor, which is perhaps not surprising given the high desiccant liquid-to-gas circulation rate used for these shakedown tests. 
The maximum possible moisture capture from a process gas occurs when the gas comes into equilibrium with the cooled strong solution entering the absorber. Lowering the desiccant's vapor pressure in order to absorb more moisture requires cooling of the desiccant and/or increasing its concentration. However, there is a practical limit to the concentration that is imposed by crystallization of the desiccant; desiccant concentrations in excess of the saturation concentration for a given temperature will result in solid desiccant separating from solution. The crystallization-versus-vapor pressure relationship is shown in Figure 6 for solutions of $\mathrm{CaCl}_{2}$. In Figure 6, the operating conditions for the LDDS lie above the crystallization boundary but below the saturation curve for pure water. The water-absorbing potential is indicated by the water vapor pressure of the cooled strong solution, and the lowest pressure for any strong solution temperature occurs at the crystallization boundary. The slight discontinuity around $29^{\circ} \mathrm{C}$ is due to the formation of different hydrate phases. In order to maximize water recovery, the concentration of the strong desiccant solution should approach the crystallization boundary as closely as possible without introducing operational issues.

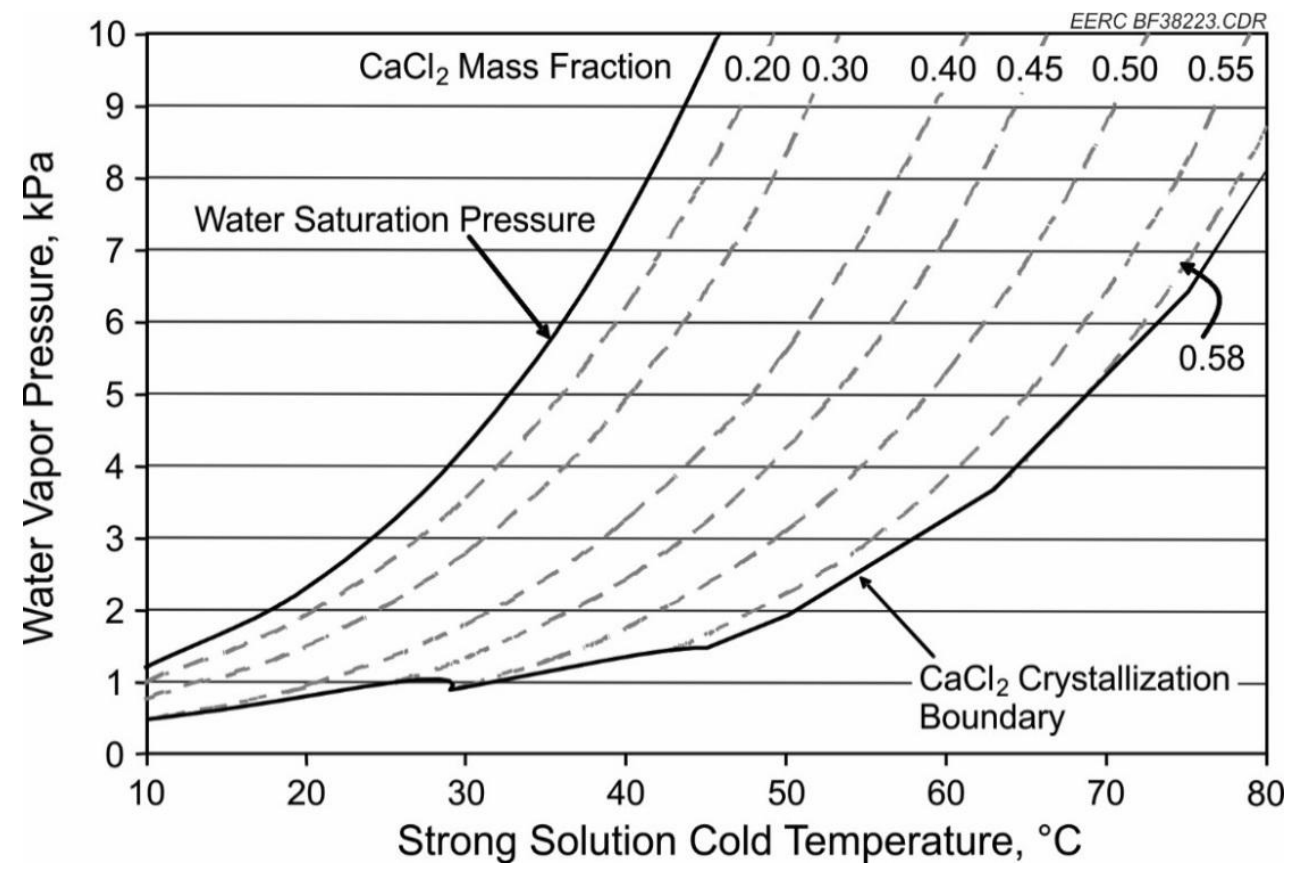

Figure 6. Minimum vapor pressures achievable with $\mathrm{CaCl}_{2}$.

\subsection{Water Quality}

Product water samples from the pilot LDDS were routinely collected during the test runs. For the four test days under discussion, ten product water samples were collected and analyzed for suspected contaminants. These included standard measures of water quality such as $\mathrm{pH}$, total dissolved solids (TDS), and total suspended solids (TSS); the constituent components of the desiccant, calcium, and chloride; and suspected contaminants from the flue gas or upstream processes, i.e., nitrate, sulfate, and carbon. 
The water analyses results are summarized in Table 4 as an average value since no discernible trend was observed in the results. Also included in Table 4 are selected analysis results for a deionized (DI) water sample and a city tap water sample analyzed during a previous study (Folkedahl et al., 2006). In that previous study, the product water $\mathrm{pH}$ was similar to but slightly less acidic than DI water. However, product water from the current tests was consistently basic and is suspected to be caused by carryover of MEA solution from either the upstream $\mathrm{CO}_{2}$ absorber or stripper.

Table 4. Product Water Analysis Results for LDDS Test Series

\begin{tabular}{lccc|ccc}
\hline & $\begin{array}{c}\text { LDDS Product Water } \\
\text { Standard }\end{array}$ & $\begin{array}{c}\text { ten samples) } \\
\text { Maximum } \\
\text { Deviation }\end{array}$ & $\begin{array}{c}\text { LDDS } \\
\text { Value }\end{array}$ & $\begin{array}{c}\text { Product } \\
\text { Water }^{\mathbf{a}, \mathbf{b}}\end{array}$ & $\begin{array}{c}\text { Deionized }_{\text {Water }^{\mathbf{a}}} \\
\text { Average }\end{array}$ & $\begin{array}{c}\text { City Tap } \\
\text { Water }^{\mathbf{a}}\end{array}$ \\
\hline $\mathrm{pH}$ & 10.45 & $(0.22)$ & 10.64 & 4.65 & 4.31 & 8.47 \\
$\mathrm{TDS}, \mathrm{mg} / \mathrm{L}$ & 49 & $(25)$ & 105 & 17.6 & $<1$ & 251 \\
$\mathrm{TSS}, \mathrm{mg} / \mathrm{L}$ & $<10$ & $(\mathrm{~N} / \mathrm{A})$ & $<10$ & $<10$ & $<10$ & $<10$ \\
$\mathrm{Ca}, \mathrm{mg} / \mathrm{L}$ & 1.6 & $(2.1)$ & 6.2 & 1.1 & $<0.09$ & 44.3 \\
$\mathrm{Cl}, \mathrm{mg} / \mathrm{L}$ & 4.1 & $(1.2)$ & 6.8 & 2.2 & $<1$ & $<1$ \\
$\mathrm{NO}_{3}, \mathrm{mg} / \mathrm{L}$ & $<1$ & $(\mathrm{~N} / \mathrm{A})$ & $<1$ & $<1$ & $<1$ & 2 \\
$\mathrm{SO}_{4}, \mathrm{mg} / \mathrm{L}$ & 8.2 & $(7.0)$ & 22 & $<1$ & $<1$ & 93.6 \\
$\mathrm{Na}^{\mathrm{mg} / \mathrm{L}}$ & 2.2 & $(1.4)$ & 5.2 & - & - & - \\
Total C, mg/L & 101.2 & $(10.4)$ & 119 & - & - & - \\
Inorganic C, mg/L & 4.9 & $(1.5)$ & 7.8 & - & - & - \\
Organic C, mg/L & 96.2 & $(11.2)$ & 114 & - & - & - \\
\hline
\end{tabular}

${ }^{\mathrm{a}}$ Results are included from a previous study (Folkedahl et al., 2006).

${ }^{\mathrm{b}}$ Product water from natural gas combustion flue gas.

\subsection{Energy Consumption}

The corresponding energy balance for the experimental work is shown in Figure 7. The primary source of thermal energy into the system was the weak solution heating before it entered the evaporator. Lesser quantities of heat were evolved from the absorption of flue gas moisture and the small amount of recovered energy from the flue gas heat exchanger. Cooling, or heat dissipation from the system, occurred in the strong solution cooler prior to the absorber and as a result of the evaporative cooling that took place in the evaporator as moisture flashed from the working fluid. Overall in Figure 7, the heat rejection was consistently lower than the calculated heat input; this was assumed to be the result of unaccounted-for heat losses to the environment.

In an idealized liquid desiccant dehumidification cycle, the flash evaporative cooling, which is proportional to water production, should be of the same magnitude as the heat of absorption, but it is significantly larger in Figure 7 because of several factors. First, the heat generated by moisture absorption in the column is split between heating the solution and heating the flue gas. Furthermore, heat was lost and dissipated to the ambient from the uninsulated 


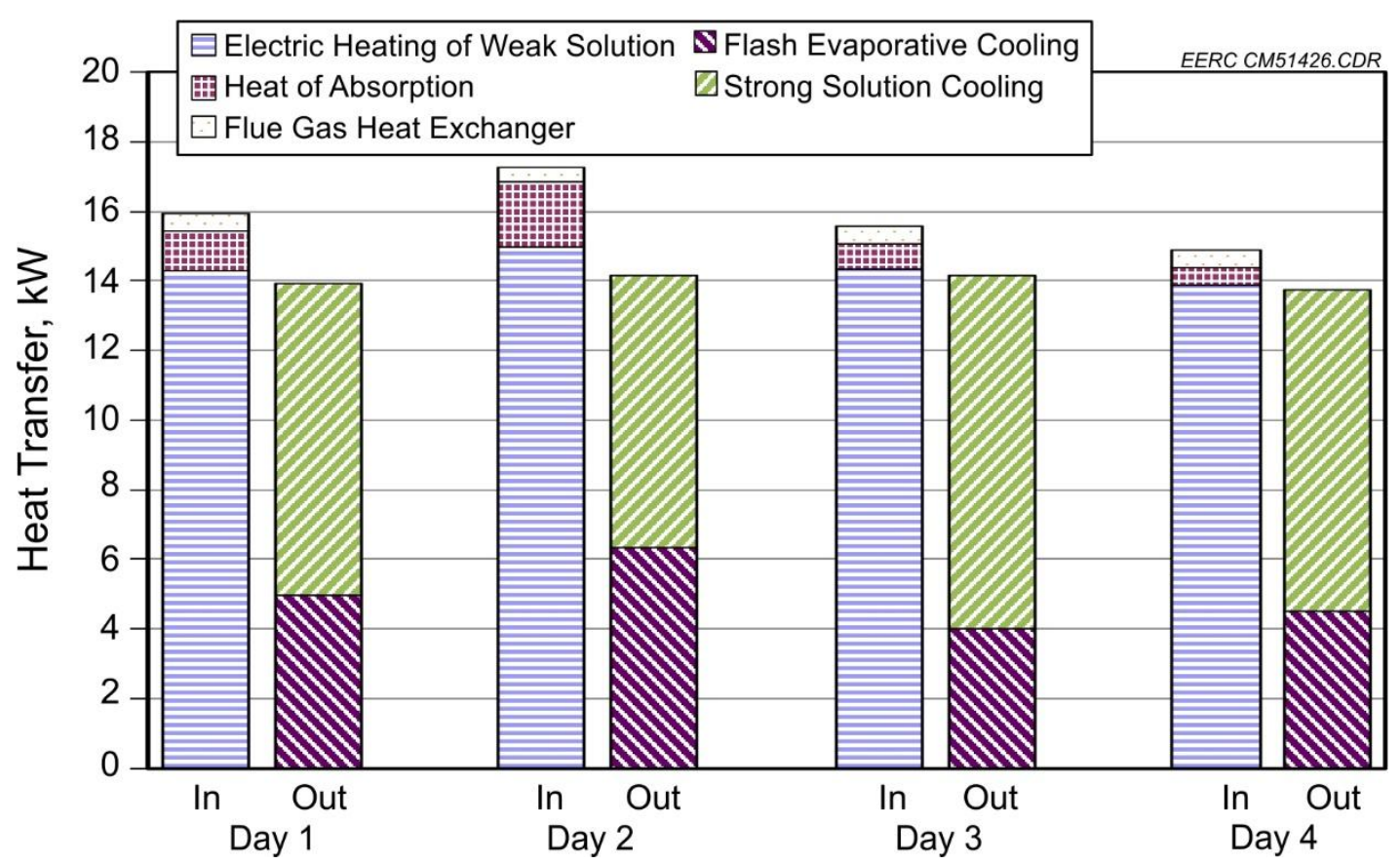

Figure 7. LDDS energy balance summary.

absorber. Finally, for all of the cases, slightly more water was collected than was absorbed from the flue gas, and this excess water appears to have come from evaporation of water from the desiccant solution. Since it was never absorbed, this component of moisture would not result in a corresponding heat of absorption.

As indicated in Figure 7, the electric heat input makes up the overwhelming majority of energy into the system, while the solution cooler is the primary outlet for thermal energy dissipation. These thermal swings are necessary to drive the separation process, but they could be conducted more efficiently by incorporating a solution heat exchanger like those used in absorption refrigeration cycles. In a solution heat exchanger, the hot strong solution exiting the evaporator would be used to preheat the cooler weak solution exiting the absorber column. Because of the poor thermal energy recycling within the pilot-scale LDDS, it was not possible to operate the system autothermally, i.e., without external heat input, as observed in previous studies (Folkedahl et al., 2006). In cases when the external heat input was turned off, the system was not able to maintain a temperature sufficient for water desorption.

\section{4. $\mathrm{CO}_{2}$ CAPTURE APPLICATION}

Addition of CDR significantly increases the water intensity of power production and, in turn, the need for mitigating technologies for fossil fuel-fired plants. However, the relative opportunity for flue gas water recovery decreases with the implementation of $\mathrm{CO}_{2}$ capture since the exhaust gases are typically cooled as much as is feasible to improve performance of the $\mathrm{CO}_{2}$ separation process. This means that more of the flue gas moisture is condensed and recycled internally and less is vented to the atmosphere or sent to the compression train. In standard 
amine-based CDR, the exhaust streams that are available for moisture recovery include the $\mathrm{CO}_{2}$ product stream (prior to compression and dehydration), the $\mathrm{N}_{2}$-rich exhaust from the $\mathrm{CO}_{2}$ absorber, and the FGD exhaust (in the case of less than $100 \%$ treatment of the flue gas). The characteristics of these streams are summarized in Table 5 along with the relative flows of each for three evaluation scenarios: no $\mathrm{CO}_{2}$ capture, $90 \% \mathrm{CO}_{2}$ capture, and $40 \% \mathrm{CO}_{2}$ capture (roughly enough to meet an 1100-lb- $\mathrm{CO}_{2} / \mathrm{MWh}$-gross limit). Stream compositions were based on streams 16, 19, and 21 from NETL Case 12, which was a supercritical pulverized coal plant with CDR (U.S. Department of Energy National Energy Technology Laboratory, 2007), except that the temperatures of Streams 19 and 21 where assumed to be somewhat higher in order to represent a hotter and more limiting environmental condition. As the results show, the relative amount of recoverable water with a LDDS does decrease with the addition of $\mathrm{CO}_{2}$ capture, but referring back to the breakdown of water uses in Table 1, it appears at least possible to recover enough water for the non-cooling tower makeup.

Table 5. Summary of Desiccant Water Harvest Potential with and Without CDR

\begin{tabular}{|c|c|c|c|}
\hline & FGD Exhaust & $\begin{array}{c}\text { Flow Stream } \\
\mathrm{CO}_{2} \text { Absorber } \\
\text { Exhaust } \\
\end{array}$ & $\mathrm{CO}_{2}$ Product \\
\hline \multicolumn{4}{|l|}{ Composition, vol\% } \\
\hline $\mathrm{N}_{2}$ & 66.9 & 87.9 & 0 \\
\hline $\mathrm{CO}_{2}$ & 13.3 & 1.7 & 95.4 \\
\hline $\mathrm{H}_{2} \mathrm{O}$ & 16.7 & 7.3 & 4.6 \\
\hline $\mathrm{O}_{2}$ & 2.4 & 3.1 & 0 \\
\hline Temperature, ${ }^{\circ} \mathrm{C}$ & 57 & 55 & 40 \\
\hline Pressure, $\mathrm{kPa}$ & 104.8 & 101.3 & 162.1 \\
\hline \multicolumn{4}{|l|}{ Flow Scenarios, kg/hr } \\
\hline $\mathrm{No} \mathrm{CO}_{2}$ Capture $^{\mathrm{a}}$ & $2,180,000$ & 0 & 0 \\
\hline $40 \% \mathrm{CO}_{2}$ Capture & $1,730,000$ & $1,000,000$ & 254,000 \\
\hline $90 \% \mathrm{CO}_{2}$ Capture & 0 & $2,430,000$ & 580,000 \\
\hline $\begin{array}{l}\text { Maximum LDDS } \mathrm{H}_{2} \mathrm{O} \\
\text { Capture per Stream, }{ }^{\mathrm{b}} \%\end{array}$ & 94.2 & 93.9 & 77.4 \\
\hline \multicolumn{4}{|c|}{ Total Water Harvest Potential, \% of plant raw water makeup } \\
\hline No $\mathrm{CO}_{2}$ Capture & & 17.4 & \\
\hline $40 \% \mathrm{CO}_{2}$ Capture & & 11.8 & \\
\hline $90 \% \mathrm{CO}_{2}$ Capture & & 10.4 & \\
\hline
\end{tabular}




\subsection{Comparison to Dew Point Condensation}

While the magnitude of recoverable water with LDDS is diminished for a CDR-equipped plant compared to a non-CDR one, in a truly water-constrained scenario, the minimum heat rejection temperature might be restricted to save water, and in this case, desiccant-based moisture recovery might offer a desirable performance advantage. Table 6 presents equilibrium thermodynamic calculations that compare potential water recovery using a LDDS and by dew point cooling the process gas stream to the local ambient temperature sink. The example assumes moisture recovery from a saturated process gas stream at $1 \mathrm{~atm}$ and $55^{\circ} \mathrm{C}$, and both systems use the same heat rejection temperature. It is assumed that each system can cool its respective working fluid (i.e., strong solution for the LDDS and process gas for the condensation approach) to $40^{\circ} \mathrm{C}$. The minimum moisture vapor pressure for each option is the equilibrium vapor pressure that can be achieved either through contact with the desiccant or by reaching saturation conditions at the heat rejection temperature. According to the calculations, the LDDS would be able to remove $91 \%$ of the moisture in the process gas stream, while cooling the process gas to the same heat sink temperature could theoretically achieve a moisture removal of only $57 \%$. While the process gas conditions presented in Table 6 are representative of typical scrubber outlet conditions, the LDDS has an even greater advantage when lower temperature differentials exist between the process gas stream and the heat sink. To highlight this effect, the calculations of Table 6 have been extended for a wider range of inlet gas temperatures, and the resulting maximum moisture capture values are plotted in Figure 8.

As Figure 8 shows, condensation-based moisture collection cannot harvest water when the inlet gas temperature is below the available heat sink temperature (without mechanical power input for subambient cooling), but because of the hygroscopic properties of the desiccant working fluid, it is possible to extract moisture even when the available heat sink is above the process gas temperature. It should be noted that this was the case for the test conditions in Table 3.

Table 6. Water Recovery Comparisons for the LDDS and Process Gas Cooling

\begin{tabular}{lcc}
\hline Water Recovery Option & LDDS & Cooling with Condensation \\
\hline Process Gas Stream & \multicolumn{2}{c}{$\begin{array}{c}\text { Saturated at } 55^{\circ} \mathrm{C} \\
40^{\circ} \mathrm{C} \\
\text { Minimum Heat Sink Temperature }\end{array}$} \\
$\begin{array}{l}104 \mathrm{~g} / \mathrm{m}^{3} \\
\text { Water Content of Inlet Gas }\end{array}$ & \\
$\begin{array}{l}\text { Minimum Moisture Vapor Pressure at } \\
\quad \text { Process Gas Outlet }\end{array}$ & $1.73 \mathrm{kPa}^{*}$ & $7.42 \mathrm{kPa}$ \\
$\begin{array}{l}\text { Equilibrium Water Content at Outlet } \\
\text { Maximum Moisture Capture }\end{array}$ & $9.8 \mathrm{~g} / \mathrm{m}^{3}$ & $44.6 \mathrm{~g} / \mathrm{m}^{3}$ \\
\hline
\end{tabular}

* Assuming a strong solution mass fraction of $0.5 \mathrm{CaCl}_{2}$. 


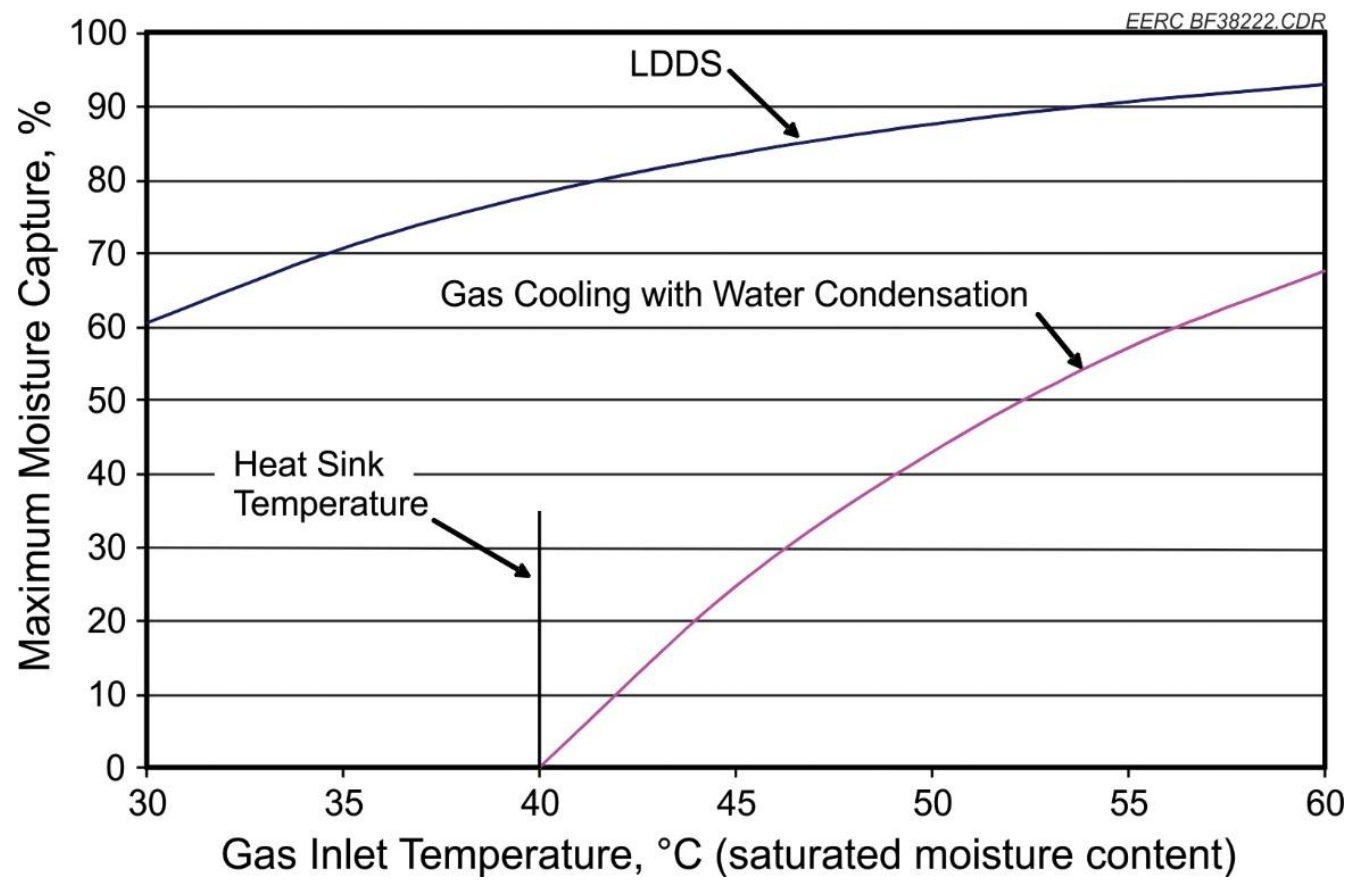

Figure 8. Comparison of maximum moisture capture values.

\subsection{Effect on Compression Power}

Depending on the temperature of the $\mathrm{CO}_{2}$ exhaust stream from the CDR, the saturated moisture volume could be $7 \%$ to $12 \%$ of the volume flow over the temperature range of $40^{\circ}$ to $50^{\circ} \mathrm{C}$. Since the initial stages of compression are the most energy intensive, it would benefit the entire compression train to preemptively remove as much of this condensable flow as possible. In order to evaluate the magnitude of the potential energy savings, three routes to achieve the same thermodynamic endpoint at the compressor outlet were considered:

- Compression of wet $\mathrm{CO}_{2}$ and separation of the condensate after intercooling.

- Moisture removal via dew point cooling followed by compression.

- Liquid desiccant-based moisture removal with subsequent compression.

The advantages of moisture removal are most apparent during the first stage of $\mathrm{CO}_{2}$ compression, which for this example was a fivefold increase over the starting pressure. This ending thermodynamic state is detailed in Figure 9 along with the three parallel paths that were considered to reach it. The power consumption results are summarized in Table 7, which shows that for the initial stage of compression, the processes of wet compression and dew point cooling require roughly the same magnitude of input power, while using a LDDS to predry the $\mathrm{CO}_{2}$ results in an input power savings of nearly $6 \%$. However, when put in the context of the entire amount of compression energy needed to reach $160 \mathrm{~atm}$, the energy savings from LDDS moisture removal is roughly $2 \%$. 


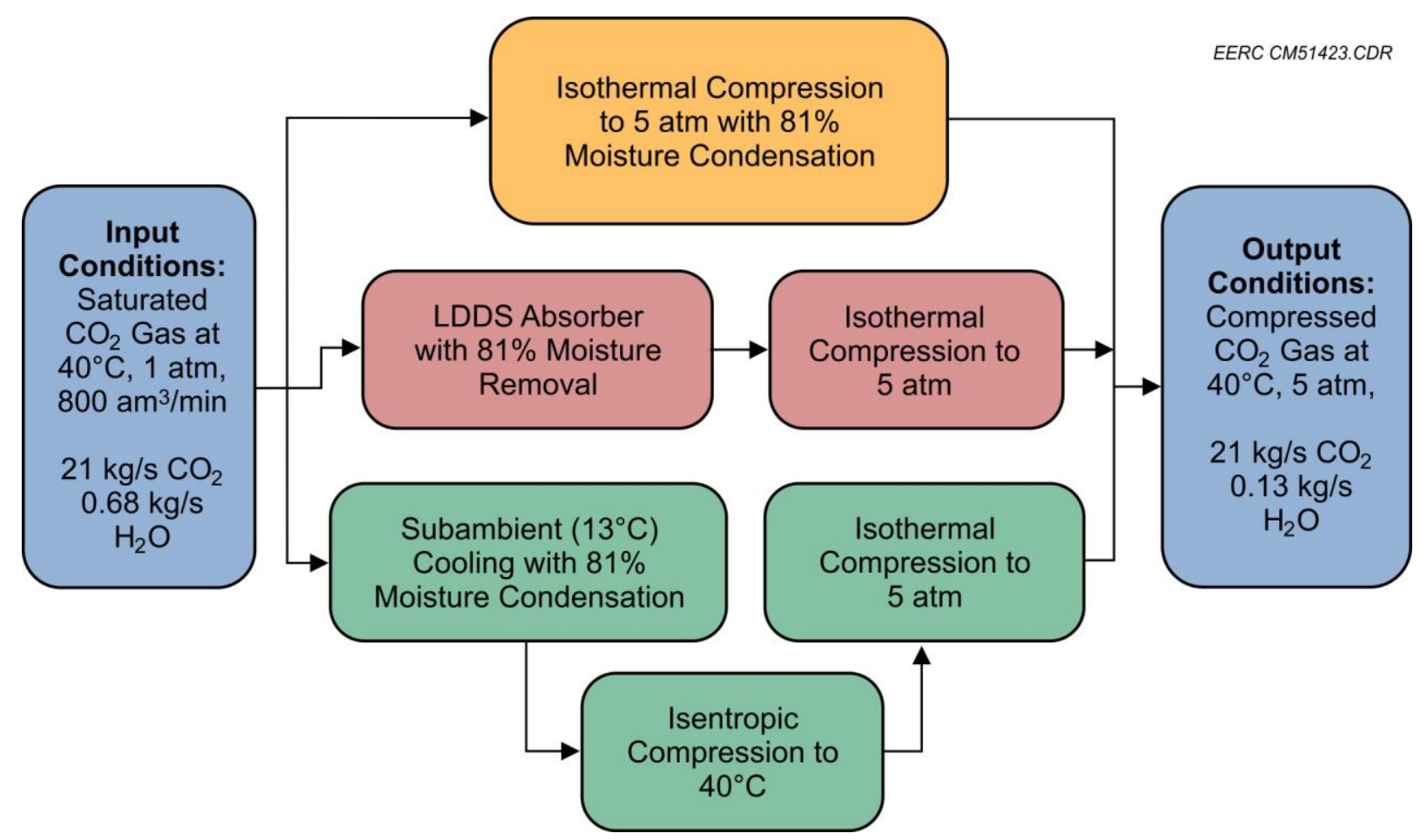

Figure 9. Graphical representation of the three routes considered to reach the stated output condition.

The savings in mechanical power for the LDDS stems from the fact that thermal energy is largely substituted for the mechanical energy that would otherwise be needed to remove the moisture vapor. For the conditions of Table 7, it was estimated that 4.49 MWth of low-grade thermal energy would be needed to drive the LDDS.

Table 7. Compressor Power Estimates for Three Processing Routes

\begin{tabular}{lcc}
\hline Option & $\begin{array}{c}\text { Compression Stage Power } \\
\text { Input to Reach 5 } \mathbf{a t m}^{\mathbf{a}}\end{array}$ & $\begin{array}{c}\text { Entire Compression Train } \\
\text { Power to Reach 160 } \mathbf{~ a t m}^{\mathbf{c}}\end{array}$ \\
\hline Wet Compression & $3.10 \mathrm{MWe}$ & $9.80 \mathrm{MWe}$ \\
Dew Point Cooling & $3.15 \mathrm{MWe}$ & $9.84 \mathrm{MWe}$ \\
Desiccant Absorption & $2.92 \mathrm{MWe}$ & $9.61 \mathrm{MWe}$ \\
\hline
\end{tabular}

\footnotetext{
${ }^{a}$ Assumes a $70 \%$ isentropic compressor efficiency for all cases.

${ }^{\mathrm{b}}$ Also includes cooling power input based on a coefficient of performance of 6.4.

${ }^{\mathrm{c}}$ The remaining compression stages beyond 5 atm are treated equally.
}

\section{CONCLUSIONS}

Liquid desiccant dehumidification is a proven and robust method to remove excess moisture from process gas streams, and it can be applied to a number of power production processes. The experimental results presented show near-equilibrium-level rates of moisture 
capture and good-quality product water for the test runs. The results also highlight opportunities for process improvement that could lower the quantity of heat input to the LDDS.

While it appears that a power plant equipped with a CDR system does not have as great a potential for flue gas water recovery compared to one without CDR, desiccant dehumidification might be useful as a heat-driven moisture management tool within a $\mathrm{CO}_{2}$ capture system. This is particularly applicable for situations where process heat rejection temperatures are high because of the ambient environment or there is a desire to minimize water use for wet cooling because a LDDS can remove and recover more moisture than a simple dew point cooling process can, given equivalent heat rejection temperatures. If this advantage is applied to the $\mathrm{CO}_{2}$ stream entering the compression train, the reduced volume flow associated with the desiccant's absorption of excess moisture vapor could result in an incremental decrease in compressor power consumption.

\section{ACKNOWLEDGMENTS}

The LDDS work was conducted by the EERC, an agency of the University of North Dakota, and is based upon work sponsored by DOE NETL under Cooperative Agreement No. DE-FC26-08NT43291, the $\mathrm{CO}_{2}$ Capture Project Consortium (BP, Chevron, ENI, BR Petrobas, Shell, and Suncor); Arthur J. Gallagher; Constellation Power Source Generation, Inc.; GE Global Research; Hitachi Power Systems America, Ltd.; Huntsman Petrochemical Corporation; Nebraska Public Power District; the North Dakota Industrial Commission; and PPL Montana, LLC (Puget Sound Energy, Portland General Electric, Avista, and PacificCorp).

\section{DOE DISCLAIMER}

This work was sponsored by an agency of the United States Government. Neither the United States Government, nor any agency thereof, nor any of their employees, makes any warranty, express or implied, or assumes any legal liability or responsibility for the accuracy, completeness, or usefulness of any information, apparatus, product, or process disclosed, or represents that its use would not infringe privately owned rights. Reference herein to any specific commercial product, process, or service by trade name, trademark, manufacturer, or otherwise does not necessarily constitute or imply its endorsement, recommendation, or favoring by the United States Government or any agency thereof. The views and opinions of authors expressed herein do not necessarily state or reflect those of the United States Government or any agency thereof.

\section{NDIC DISCLAIMER}

Work was done by the EERC pursuant to an agreement partially funded by the Industrial Commission of North Dakota, and neither the EERC nor any of its subcontractors nor the North Dakota Industrial Commission nor any person acting on behalf of either: 
A. Makes any warranty or representation, express or implied, with respect to the accuracy, completeness, or usefulness of the information contained herein or that the use of any information, apparatus, method, or process disclosed herein may not infringe privately owned rights; or

B. Assumes any liabilities with respect to the use of, or for damages resulting from the use of, any information, apparatus, method, or process disclosed herein.

Reference herein to any specific commercial product, process, or service by trade name, trademark, manufacturer, or otherwise does not necessarily constitute or imply its endorsement, recommendation, or favoring by the North Dakota Industrial Commission. The views and opinions of authors expressed herein do not necessarily state or reflect those of the North Dakota Industrial Commission.

\section{REFERENCES}

Conde, M., 2004. Properties of aqueous solutions of lithium and calcium chlorides: formulations for use in air conditioning equipment design. International Journal of Thermal Sciences 43, 367-382.

Hetland, J., 2013. Water balance in oxy-combustion compared with post-combustion schemes. Energy Procedia 37, 1322-1330.

Folkedahl, B., Weber, G., Collings, M., Copen, J., Sullivan, T., Deen, P., 2006. Water extraction from coal-fired power plant flue gas. Final Report. 2006-EERC-12-05.

Folkedahl, B., Martin, C., Dunham, D., 2010. Water and energy sustainability and technology. Subtask 5.3 Final Report. 2010-EERC-09-10.

Kvamsdal, H., Hetland, J., Haugen, G., Svendsen, H., Major, F., Karstad, V., Tjellander, G., 2010. Maintaining a neutral water balance in a 450 MWe NGCC-CCS power system with post-combustion carbon dioxide capture aimed at offshore operation. International Journal of Greenhouse Gas Control 4, 613-622.

Martin, C., Pavlish, J., 2013. Testing of an advanced dry cooling technology for power plants. Subtask 5.10 Final Report. 2013-EERC-09-09.

Martin, C., Zhuang, Y., 2014. Water-saving liquid-gas conditioning system. U.S. Patent $8,628,603$.

Talati, S., Zhai, H., Morgan, M., 2014. Water impacts of $\mathrm{CO}_{2}$ emission performance standards for fossil fuel-fired power plants. Environ. Sci. Technol. 48, 11769-11776.

U.S. Department of Energy National Energy Technology Laboratory, 2007. Cost and performance baseline for fossil energy plants. vol. 1: bituminous coal and natural gas to electricity final report. DOE/NETL-2007/1281. 
U.S. Department of Energy National Energy Technology Laboratory, 2009. Water requirements for existing and emerging thermoelectric plant technologies, April 2009 revision. DOE/NETL-402/080108.

Zhai, H., Rubin, E., Versteeg, P., 2011. Water use at pulverized coal power plants with postcombustion carbon capture and storage. Environ. Sci. Technol. 45, 2479-2485. 